University of Nebraska - Lincoln

DigitalCommons@University of Nebraska - Lincoln

\title{
Invertebrate Egg Banks of Restored, Natural, and Drained Wetlands in the Prairie Pothole Region of the United States
}

Robert A. Gleason

U.S. Geological Survey, rgleason@usgs.gov

Ned H. Euliss Jr.

U.S. Geological Survey, ceuliss@usgs.gov

Daniel E. Hubbard

South Dakota State University

Walter G. Duffy

U.S. Geological Survey

Follow this and additional works at: https://digitalcommons.unl.edu/usgsnpwrc

Gleason, Robert A.; Euliss, Ned H. Jr.; Hubbard, Daniel E.; and Duffy, Walter G., "Invertebrate Egg Banks of Restored, Natural, and Drained Wetlands in the Prairie Pothole Region of the United States" (2004). USGS Northern Prairie Wildlife Research Center. 275.

https://digitalcommons.unl.edu/usgsnpwrc/275

This Article is brought to you for free and open access by the US Geological Survey at DigitalCommons@University of Nebraska - Lincoln. It has been accepted for inclusion in USGS Northern Prairie Wildlife Research Center by an authorized administrator of DigitalCommons@University of Nebraska - Lincoln. 


\title{
INVERTEBRATE EGG BANKS OF RESTORED, NATURAL, AND DRAINED WETLANDS IN THE PRAIRIE POTHOLE REGION OF THE UNITED STATES
}

\author{
Robert A. Gleason ${ }^{1}$, Ned H. Euliss, Jr. ${ }^{1}$, Daniel E. Hubbard ${ }^{2}$, and Walter G. Duffy ${ }^{3}$ \\ ${ }^{1}$ U.S. Geological Survey \\ Northern Prairie Wildlife Research Center \\ 8711 37th Street Southeast \\ Jamestown, North Dakota, USA 58401-7317 \\ ${ }^{2}$ South Dakota State University \\ Department of Wildlife and Fisheries Sciences \\ Brookings, South Dakota, USA 57007 \\ ${ }^{3}$ California Cooperative Fish and Wildlife Research Unit \\ U.S. Geological Survey \\ Humboldt State University \\ Arcata, California, USA 95521
}

\begin{abstract}
Analogous to 'seed banks,' 'egg banks' are important for seasonal succession and maintenance of invertebrate species diversity throughout wet and dry cycles in the prairie pothole region. Further, recruitment of invertebrates from relic egg banks in the sediments and dispersal of eggs into wetlands is believed to be important for reestablishment of invertebrates in recently restored wetlands. Alhough tens-ofthousands of wetlands have been restored in the prairie pothole region of the United States, studies have not been conducted to evaluate the recovery of invertebrate egg banks in restored wetlands. We used taxon richness and abundance as indicators of potential egg bank recovery and compared these parameters in restored wetlands to those of non-drained and drained wetlands with a history of cultivation and also to reference wetlands with no history of cultivation. We found few significant differences among wetland categories within three physiographic regions (Glaciated Plains, Missouri Coteau, and Prairie Coteau). Most statistical comparisons indicated that restored wetlands had invertebrate egg banks similar to reference, nondrained, and drained wetlands. The one exception was drained seasonal wetlands in the Glaciated Plains, which had significantly lower taxon richness and invertebrate abundance than the other wetland categories. Trends did suggest that invertebrate egg bank taxon richness and abundance are increasing in restored seasonal wetlands relative to their drained analogues, whereas a similar trend was not observed for restored semi-permanent wetlands. Although recovery was not related to years since restoration, comparisons of restored wetlands with reference wetlands suggest that recovery potential may be inversely related to the extent of wetland drainage and intensive agriculture that varies spatially in the prairie pothole region. Our research suggests that periodic drawdowns of semi-permanent restored wetlands may be needed to promote production and development of invertebrate egg banks. Inoculation of restored wetlands may also be needed in areas where extensive wetland drainage has resulted in fewer wetland habitats to provide sources of passively dispersed eggs to newly restored wetlands.
\end{abstract}

Key Words: agricultural impacts, aquatic invertebrates, Cladocera, egg banks, ephippia, resting eggs

\section{INTRODUCTION}

Numerous wetlands have been restored in the prairie pothole region (PPR) of the United States to mitigate for past wetland losses. Restoration of these wetlands typically consists of plugging ditch or tile drains and relying on natural processes for recolonization of aquatic invertebrates. Natural recovery of invertebrates results from remnant invertebrate egg banks, refugial populations, or by dispersal of propagules or adults into wetlands from surrounding sources. Insects with aerial dispersal capabilities have been shown to recolonize restored wetlands rapidly (LaGrange and Dinsmore 1989, Sewell 1989, Delphey 1991, Hemesath 1991, VanRees-Siewert 1993). In contrast, some studies have indicated that less mobile and passively dispersed invertebrates were poorly represented in restored wetlands (Delphey 1991, VanRees-Siewert 1993, Brown et al. 1997). This latter group, which includes members of the class Crustacea (e.g., the or- 
ders Cladocera, Conchostraca, and Ostracoda), are capable of withstanding extreme hydrologic events by producing drought-resistant reproductive structures (e.g., resting eggs) that remain viable in dry sediments for many years (Wiggins et al. 1980, Pennak 1989, Hairston et al. 1995, Euliss et al. 1999). Consequently, these species are important constituents of the aquatic invertebrate community inhabiting dynamic prairie wetlands.

The importance of 'egg banks' in maintaining invertebrate species richness throughout both short- and long-term hydrologic cycles (Wiggins et al. 1980, De Stasio 1989, Euliss et al. 1999) is analogous to the importance of persistent 'seed banks' in maintaining plant diversity in prairie wetlands (van der Valk and Davis 1978, van der Valk 1981). Although the role of remnant egg banks in repopulating restored wetlands has not been evaluated, numerous agriculturally related factors may potentially exert negative impacts on egg bank viability. For example, intensive agriculture and prolonged drainage have been shown to accelerate erosion rates, amplify sediment laden-runoff, and increase inputs of agrichemicals and fertilizers within basins (Martin and Hartman 1987, Neely and Baker 1989, Dieter 1991, Gleason and Euliss 1998, Gleason 2001). Such impacts have been shown to decrease species diversity and abundance of egg banks (Euliss and Mushet 1999, Euliss et al. 2001, Gleason et al. 2003). Further, extensive or prolonged drainage of wetlands in the PPR has resulted in fewer wetland habitats to provide sources of passively dispersed eggs to recently restored wetlands, which may further impede reestablishment of certain invertebrates (e.g., crustaceans).

In our study, we compared invertebrate egg banks of restored wetlands to those of non-drained and drained wetlands with a history of cultivation and also to high quality natural wetlands with no history of cultivation or drainage. Additionally, we evaluated how invertebrate egg banks vary by restoration age and compared how recovery of invertebrate egg banks varies among physiographic regions that vary in intensity of wetland drainage and agricultural land-use disturbances.

\section{STUDY AREA AND SAMPLING DESIGN}

Our study area included wetlands in the United States portion of the PPR. This portion of the PPR ( $36 \%$ of the $777,000 \mathrm{~km}^{2}$ in North America) includes large areas of North Dakota $\left(\approx 101,010 \mathrm{~km}^{2}\right)$, South Dakota $\left(\approx 69,930 \mathrm{~km}^{2}\right)$, Minnesota $\left(\approx 54,390 \mathrm{~km}^{2}\right)$, Iowa $\left(\approx 31,080 \mathrm{~km}^{2}\right)$, and Montana $\left(\approx 21,450 \mathrm{~km}^{2}\right)$ (Grue et al. 1986). Major landforms of glacial origin in the region include the Missouri Coteau, Prairie Coteau, and Glaciated Plains (also known as drift prairie)

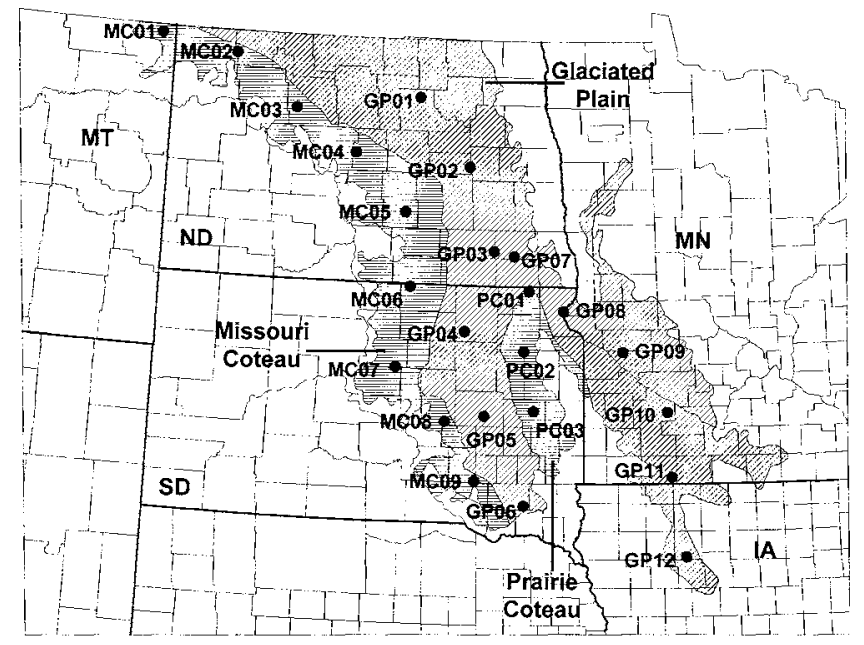

Figure 1. Location of wetland sampling points/areas in the Glaciated Plains (GP01-GP12), Missouri Coteau (MC01MC09), and Prairie Coteau (PC01-PC03) physiographic regions in the prairie pothole region of the United States (map based on Kantrud 1993 and Bluemle 1977).

physiographic regions (Figure 1). The Missouri and Prairie Coteau are areas where stagnation moraine and dead-ice moraine processes predominated and resulted in a rugged area with closely spaced hills and depressions. In contrast, the Glaciated Plains region was derived mostly from ground moraine processes, which left behind a gently rolling glacial landscape. Climate of the region varies along a northwest-to-southeast gradient, with precipitation and temperature increasing toward the southeast (Visher 1966). Collectively, these factors have resulted in spatial and temporal differences in agricultural development, including extent of wetland drainage (Figure 2) and crop type (small grains in North Dakota to more agriculturally intensive row crops in Minnesota and Iowa; Galatowitsch and van der Valk 1994).

We used a systematic sampling design stratified by physiographic region to select a representative geographic sample of wetlands along the northwest-tosoutheast climatic and land-use gradients in the PPR. Using a geo-referenced map of the PPR depicting the three major physiographic regions (Figure 1), we drew a line along the medial portions of each physiographic region that follows the long natural orientation of these regions. Along each axis line, we systematically identified nine sampling points in the Missouri Coteau, three in the Prairie Coteau, and 12 in the Glaciated Plains (Figure 1); allocation of sampling points was proportional to the linear length of each physiographic region. Near each sampling point, we attempted to find a seasonal and semi-permanent wetland (Class III and IV wetlands; Stewart and Kantrud 1971) in each of the following categories: (1) restored wetlands $<5$ years 


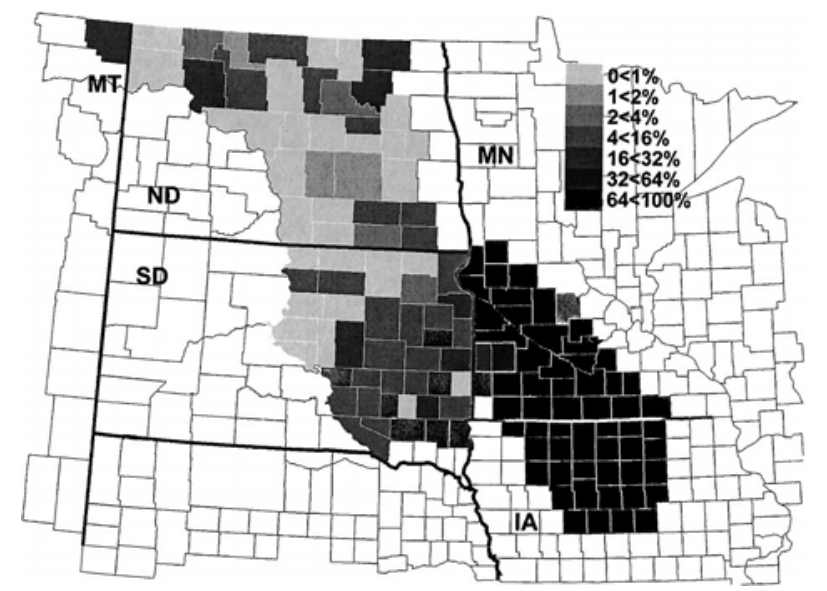

Figure 2. Percent of total wetland area drained in counties of the prairie pothole region of the United States. County estimates are based on 1992 National Resources Inventory (NRI) (USDA/SCS 1994). Wetland areas in the NRI database with Food Security Act classifications indicating that wetland areas have been drained, dredged, filled, leveled, or otherwise manipulated to make production of an agricultural commodity possible were treated as drained.

old in Conservation Reserve Program (CRP) or similar grasslands (i.e., prior farmed lands planted back to perennial grasses), (2) restored wetlands $>5$ years old in CRP-type habitats, (3) drained wetlands in CRPtype habitats, (4) non-drained wetlands in CRP-type habitats, and (5) reference wetlands in native grassland with no history of cultivation in the wetland basin or the surrounding catchment. Additionally, we attempted to restrict the size of seasonal wetlands to $0.4-0.8$ ha and semi-permanent wetlands to $2.5-5.5 \mathrm{ha}$; size ranges were based on average basin size (mean \pm sd) of seasonal and semi-permanent wetlands in North and South Dakota (National Wetland Inventory Data). Our sampling effort resulted in the selection of 204 wetlands; however, only 203 were used for this study (Figure 3). Ideally, our sampling effort would have resulted in the selection of 240 wetlands, but certain wetland categories were not readily available near each sampling point. Size of seasonal (mean $=0.87$ ha, sd $=0.53$ ) and semi-permanent (mean $=3.64 \mathrm{ha}, \mathrm{sd}=$ 1.88) wetlands selected was similar to the size ranges targeted.

\section{MATERIALS AND METHODS}

Field Collection and Laboratory Processing of Experimental Material

During June to September 1997, we collected soil samples (i.e., invertebrate egg bank samples) from the 203 wetlands selected for study. We selected four randomly established transects that radiated from the cen-

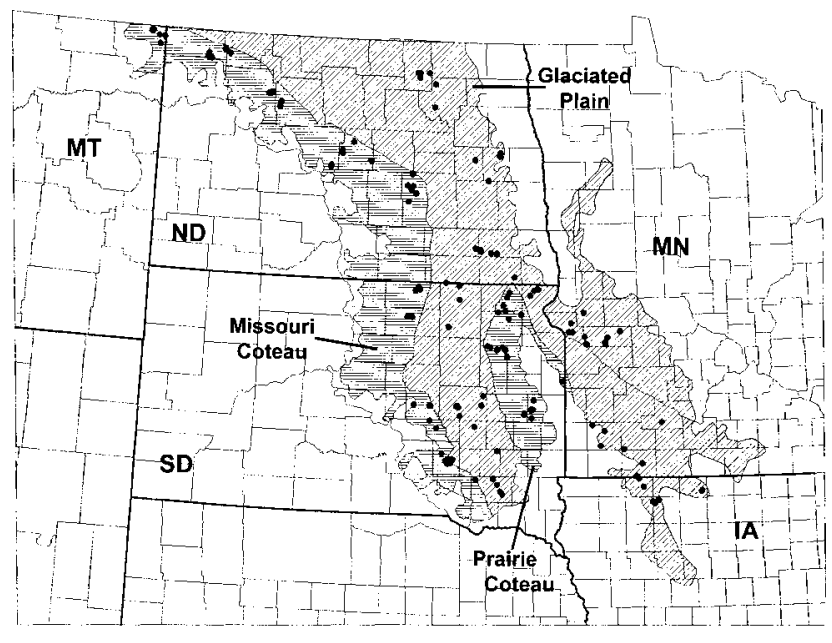

Figure 3. Locations of wetlands sampled for invertebrate egg banks during 1997 in the Glaciated Plains, Missouri Coteau, and Prairie Coteau physiographic regions in the prairie pothole region of the United States.

ter of each wetland to the outer edge of the wet-meadow zone (wetland zone classification follows Stewart and Kantrud 1971). Along each transect, we collected three soil cores to a depth of $5 \mathrm{~cm}$ in the wet-meadow and shallow-marsh zones using a $7.5-\mathrm{cm}$-diameter corer. Samples were stored in a freezer $\left(<0^{\circ} \mathrm{C}\right)$ until needed for laboratory experiments. In the laboratory, we composited the soil samples from each wetland (samples for both zones combined) and mixed and sieved the soils to remove litter, roots, and tubers. One subsample $\left(380 \mathrm{~cm}^{3}\right)$ from each composite sample (n $=203$ ) was spread evenly over the surface of a plastic flat $(19.5 \times 19.5 \times 6 \mathrm{~cm})$. This resulted in a soil depth of ca. $1 \mathrm{~cm}$.

\section{Incubation Experiments}

We performed invertebrate incubation experiments using aquaria in a controlled environment room at the U.S. Geological Survey's Northern Prairie Wildlife Research Center, Jamestown, ND. Four experimental trials were necessary to incubate soils from all the wetland replicates because the number of wetland replicates exceeded the number of aquaria available. Trials were restricted by wetland class and physiographic region. Order of trials and experiment start dates are as follows: (1) Glaciated Plains seasonal wetlands, 31 January 1998, (2) Missouri and Prairie Coteau seasonal wetlands, 4 April 1998, (3) Glaciated Plains semipermanent wetlands, 10 June 1998, and (4) Missouri and Prairie Coteau semi-permanent wetlands, 5 August 1998. During each trial, we randomly assigned flats containing wetland soils to 37.8 -L glass aquaria containing water adjusted to a specific conductance within 
the range typical of seasonal $\left(700 \mu \mathrm{S} \mathrm{cm}^{-1}\right)$ and semipermanent $\left(1400 \mu \mathrm{S} \mathrm{cm}^{-1}\right)$ wetlands (Stewart and Kantrud 1971). Samples were incubated for six weeks; temperatures were maintained at $10^{\circ} \mathrm{C}$ for the first three weeks and then raised to $20^{\circ} \mathrm{C}$ for the remainder of the experiment. The light regime was maintained at $12 \mathrm{~h}$ light: $12 \mathrm{~h}$ dark; aquaria were aerated during experiments. We checked aquaria temperatures daily and added distilled water to maintain water levels and salt concentrations. Procedures were similar to those described by Euliss and Mushet (1999). During the sixweek incubation, we harvested invertebrates every two weeks by siphoning water from the aquaria through a $0.1-\mathrm{mm}$ screen to concentrate invertebrates. The siphoned water was then returned to the aquaria. All harvested invertebrates were enumerated and identified (family or order) using keys by Pennak (1989).

\section{Statistical Analyses}

We used analysis of variance (ANOVA) to assess the influence of wetland categories (i.e., drained, restored, non-drained, and reference) on abundance and taxon richness of invertebrates incubated from egg banks. Analyses were performed separately for each wetland class-physiographic region combination using a blocked design, where sampling area was treated as a random block (e.g., GP01-GP12; Figure 1); wetlands near each sampling point were sampled during the same time frame (e.g., 3-5 days); thus, the block accounts for sources of variation associated with temporal differences in sampling and storage time. For ANOVA analyses, we used the pooled average of the two restored wetland age classes (i.e., restored $<5$ years and restored $>5$ years) within each sampling area (i.e., block). We conducted ANOVAs using the mixed model procedure (PROC MIXED) of SAS (SAS Institute, Inc. 1997). Prior to analysis, we transformed abundance data $[\ln ($ count +1$)]$ to stabilize variances (Steel and Torrie 1980). Fisher's protected least significant difference tests (LSD) were used to assess individual differences when main effects were significant (Milliken and Johnson 1984). We report back-transformed means and confidence intervals.

We used simple linear regression (PROC REG; SAS Institute, Inc. 1989) to examine the relationship of invertebrate taxon richness and abundance to restoration age (years). For these analyses, taxon richness and abundance of restored wetlands represented the difference from their paired reference wetland in each study area. For example, restored wetland taxon richness $=$ restored wetland taxon richness minus reference wetland taxon richness. Restored wetlands without a paired reference wetland were not included in the analyses. Additionally, to compare how invertebrate egg bank composition of restored wetlands varied among regions, we constructed $95 \%$ confidence interval plots of the relative difference in taxon richness and abundance between restored wetlands and reference wetlands. In conjunction with these plots, we also plotted percent of total wetland area drained in the counties where restored wetlands were sampled. County estimates of percent of total wetland area drained were based on the 1992 National Resources Inventory (NRI)(USDA/SCS 1994)(e.g., Figure 2). Wetland areas within the NRI database with a Food Security Act (FSA) wetland designation that indicate wetlands were drained, dredged, filled, leveled, or otherwise manipulated for production of an agricultural commodity were treated as drained wetlands.

\section{RESULTS}

Hatching Success and Taxon Richness

Anostracans, conchostracans, copepods, ostracods, and four families of cladocerans (Daphnidae, Macrothricidae, Chydoridae, and Bosminidae) were successfully incubated during aquarium experiments. Invertebrates successfully hatched from $74 \%$ of the 203 wetlands sampled for invertebrate egg banks. Across study regions, hatching success (percent of wetlands that hatched one or more invertebrates) for seasonal wetlands was lowest in drained wetlands (Table 1). Hatching success in semi-permanent wetlands in the Glaciated Plains and Missouri Coteau regions was generally lower in restored and drained wetlands than in non-drained and reference wetlands (Table 1).

We found only one significant $(\mathrm{P}<0.05)$ difference in taxon richness among wetland categories. Glaciated Plains seasonal wetlands showed a significant response with lower taxon richness in drained wetlands than in other wetland categories (Table 2). Taxon richness did not differ significantly among any other wetland classphysiographic region combination.

\section{Invertebrate Abundance}

In the Glaciated Plains region, mean abundance of invertebrates incubated from egg banks was significantly lower in drained seasonal wetlands than in other wetland categories (Table 3). Invertebrate abundance did not differ significantly among seasonal or semipermanent wetland categories within the Coteau regions or semi-permanents within the Glaciated Plains.

Of the eight taxa incubated successfully during aquarium experiments, only ostracods and chydorids were found to differ among wetland categories (Table 4). Mean abundance of chydorids in Glaciated Plains seasonal wetlands was highest in reference wetlands, 
Table 1. Percent of seasonal and semi-permanent reference, non-drained, restored, and drained wetlands that successfully hatched invertebrates during soil egg bank incubation experiments. Egg bank samples were collected June-September, 1997. Wetlands were located in the Glaciated Plains, Missouri Coteau, and Prairie Coteau physiographic regions of the prairie pothole region of the United States. Number in parentheses is the total number of wetland replicates (n).

\begin{tabular}{|c|c|c|c|c|c|}
\hline \multirow[b]{2}{*}{ Wetland Class } & \multirow{2}{*}{$\begin{array}{c}\text { Physiographic } \\
\text { Region }\end{array}$} & \multicolumn{4}{|c|}{ Wetland Categories } \\
\hline & & Reference & Non-drained & Restored & Drained \\
\hline \multirow[t]{4}{*}{ Seasonal } & Glaciated Plains & 91.7 (12) & $100.0(12)$ & $90.5(21)$ & $50.0(12)$ \\
\hline & Missouri Coteau & $77.8(9)$ & $88.9(9)$ & $94.1(17)$ & $71.4(7)$ \\
\hline & Prairie Coteau & $100.0(3)$ & $100.0(3)$ & $83.3(6)$ & $66.7(3)$ \\
\hline & All regions & $87.5(24)$ & $95.8(24)$ & $90.9(44)$ & $59.1(22)$ \\
\hline \multirow[t]{4}{*}{ Semi-permanent } & Glaciated Plains & $90.0(10)$ & $66.7(9)$ & $50.0(14)$ & $55.6(9)$ \\
\hline & Missouri Coteau & $77.8(9)$ & $87.5(8)$ & $58.3(12)$ & $66.7(3)$ \\
\hline & Prairie Coteau & $33.3(3)$ & $0.0(2)$ & $50.0(6)$ & $0.0(4)$ \\
\hline & All regions & $77.3(22)$ & $68.4(19)$ & $53.1(32)$ & $43.8(16)$ \\
\hline All classes & All regions & $82.6(46)$ & $83.7(43)$ & $75.0(76)$ & $52.6(38)$ \\
\hline
\end{tabular}

followed in descending order by non-drained, restored, and drained wetlands. Chydorid abundance in Missouri Coteau seasonal wetlands was greater in non-drained than in reference and drained wetlands but similar to restored wetlands. Abundance of ostracods in Glaciated Plains seasonal wetlands was significantly lower in drained wetlands than in other wetland categories, and ostracod abundance in Prairie Coteau seasonal wetlands was greater in non-drained wetlands than in other wetland categories. Mean counts of other invertebrate taxa did not differ significantly among wetland categories.

Invertebrate Egg Banks Versus Restoration Age and Regional Differences

Taxon richness and abundance of invertebrates in restored seasonal and semi-permanent wetlands did not significantly $(\mathrm{P}>0.05)$ vary with restoration age. However, restored seasonal and semi-permanent wetlands in the Missouri and Prairie Coteau regions attained invertebrate taxon richness and abundance values similar to reference wetlands (i.e., means not different from zero) (Figure 4), whereas within the Glaciated Plains, mean taxon richness in restored semi-permanent wetlands and abundance in restored seasonal and semi-permanent wetlands were lower than in reference wetlands (i.e., means less than zero). Likewise, these trends showed a relationship with differences in wetland drainage among the study regions, with greater drainage occurring in the Glaciated Plains than in the Coteau regions (Figure 4).

Overall, semi-permanent wetlands had lower percent hatching success, taxon richness, and abundance of invertebrates than seasonal wetlands (Figure 5).
Also notable was that seasonal restored wetlands within all three study regions had greater invertebrate taxon richness and abundance, as well as hatching success, than their drained analogues. In contrast, with the exception of the Prairie Coteau, a similar trend was not observed for restored semi-permanent wetlands.

\section{DISCUSSION}

We found few significant differences among wetland categories within physiographic regions. Most statistical comparisons indicated that restored wetlands had invertebrate egg banks similar to reference, nondrained, and drained wetlands. The one exception was drained seasonal wetlands in the Glaciated Plains that had significantly lower taxon richness and invertebrate abundance than the other wetland categories. Hence, with the exception of seasonal wetlands in the Glaciated Plains, egg banks of reference, non-drained, and restored wetlands did not differ significantly from drained wetlands. This is contrary to the expected, given that previous research has demonstrated that intensive agriculture and wetland drainage reduces numbers of aquatic invertebrate eggs in wetlands (Euliss and Mushet 1999, Euliss et al. 2001). Research also has shown zooplankton taxon richness to be significantly lower in agricultural wetlands relative to restored wetlands and that withdrawal of wetlands from agricultural usage is followed by increased taxon richness (Dodson and Lillie 2001).

The inability to separate drained wetlands statistically from other wetland categories is not surprising given the broad confidence intervals that surround our estimates of invertebrate taxon richness and abundance. This situation is not unique; the inherent spatial 
Table 2. Mean taxon richness and 95\% confidence intervals (in parentheses) of invertebrates incubated from soil egg bank samples collected (June-September, 1997) from seasonal and semi-permanent reference, non-drained, restored, and drained wetlands in the Glaciated Plains, Missouri Coteau, and Prairie Coteau physiographic regions of the United States prairie pothole region. Means within rows with a common letter are not significantly $(\mathrm{P}>0.05)$ different.

\begin{tabular}{|c|c|c|c|c|c|c|c|c|}
\hline \multirow[b]{2}{*}{ Wetland Class } & \multirow{2}{*}{$\begin{array}{c}\text { Physiographic } \\
\text { Region }\end{array}$} & \multicolumn{4}{|c|}{ Wetland categories } & \multicolumn{3}{|c|}{ ANOVA } \\
\hline & & Reference & Non-drained & Restored & Drained & df & $\mathrm{F}$ & $\mathrm{P}$ \\
\hline \multirow[t]{3}{*}{ Seasonal } & Glaciated Plains & $2.2 \mathrm{a}(1.5-3.0)$ & $2.1 \mathrm{a}(1.3-2.8)$ & $2.0 \mathrm{a}(1.3-2.7)$ & $1.0 \mathrm{~b}(0.3-1.7)$ & 3,31 & 3.3 & 0.033 \\
\hline & Missouri Coteau & $2.1 \mathrm{a}(1.2-3.0)$ & $2.3 \mathrm{a}(1.4-3.3)$ & $2.5 \mathrm{a}(1.5-3.4)$ & $1.9 \mathrm{a}(0.8-2.9)$ & 3,22 & 0.3 & 0.817 \\
\hline & Prairie Coteau & $1.7 \mathrm{a}(0.6-2.8)$ & $2.7 \mathrm{a}(1.6-3.8)$ & $2.5 \mathrm{a}(1.4-3.6)$ & $1.0 \mathrm{a}(0.0-2.1)$ & 3,6 & 3.9 & 0.075 \\
\hline \multirow[t]{3}{*}{ Semi-permanent } & Glaciated Plains & $1.9 \mathrm{a}(1.2-2.6)$ & $1.4 \mathrm{a}(0.6-2.2)$ & $0.8 \mathrm{a}(0.0-1.5)$ & $0.8 \mathrm{a}(0.0-1.5)$ & 3,23 & 2.5 & 0.084 \\
\hline & Missouri Coteau & $1.4 \mathrm{a}(0.6-2.2)$ & $1.4 \mathrm{a}(0.6-2.2)$ & $1.1 \mathrm{a}(0.3-1.9)$ & $1.1 \mathrm{a}(0.0-2.3)$ & 3,16 & 0.2 & 0.906 \\
\hline & Prairie Coteau & $0.3 \mathrm{a}(0.0-0.9)$ & $0.0 \mathrm{a}(0.0-0.7)$ & $0.5 \mathrm{a}(0.0-1.1)$ & $0.0 \mathrm{a}(0.0-0.6)$ & 3,5 & 1.0 & 0.454 \\
\hline
\end{tabular}

variability in the distribution of invertebrates and the lack of efficient sampling protocols that adequately address this complexity (Elliott 1977, Downing 1979, Resh 1979) often result in extreme variability within and among wetland basins (Euliss et al. 1999). Therefore, attention must also be given to trends in the information to further our understanding of invertebrate recolonization of wetlands.

Trends suggest that recovery of invertebrate egg banks in restored wetlands may vary by wetland class. With respect to seasonal wetlands in the Glaciated Plains, invertebrate taxon richness and abundance were significantly greater in restored than drained wetlands. Although not statistically unique, seasonal restored wetlands in both the Coteau regions followed a similar trend, with greater invertebrate taxon richness and abundance and hatching success than their drained analogues (Figure 5). In contrast, with the exception of the Prairie Coteau that had a low sample size, restored semi-permanent wetlands within the Missouri Coteau and Glaciated Plains had similar to lower invertebrate hatching success, taxon richness, and abundance than their drained analogues (Figure 5). These apparent trends suggest that invertebrate egg bank taxon richness and abundance is increasing in restored seasonal wetlands relative to their drained analogues, whereas a similar trend was not observed for restored semipermanent wetlands. The more rapid development of invertebrate egg banks in restored seasonal wetlands is reasonable given that most egg bank species are adapted to wetlands with temporary and seasonal water regimes. Thus, the shorter hydroperiods and more frequent drawdowns of seasonal wetlands that cue production of resting eggs (Wiggins 1980, Pennak 1989) might explain why invertebrate egg banks developed more rapidly in seasonal wetlands than in semi-permanent wetlands that have less frequent drawdowns.

There was an overall trend of semi-permanent wetlands having lower taxon richness and abundance of invertebrates than seasonal wetlands (Figure 5). This is counter to the expected because wetlands with more permanent water regimes typically contain more diverse invertebrate communities (Euliss et al. 1999, 2001). However, this generality may not apply to invertebrate egg bank taxa observed in our study. For example, Neckles et al. (1990) found that increasing water permanence in impoundments from seasonal to semi-permanent for one year dramatically reduced densities of dominant taxa (Cladocera, Ostracoda, and Culicidae) and did not increase overall taxon richness. They suggested that reduction in densities of dominant taxa was unrelated to changes in predator abundance or food resources. Rather, they suggested that semipermanent flooding eliminated environmental cues necessary for embryonic development and hatch among dominant taxa. Hence, the lower diversity and abundance of egg banks in semi-permanent wetlands relative to seasonal wetlands observed during our study is likely related to differences in water regimes that provide cues necessary for production of invertebrate egg bank taxa. The lower invertebrate abundance and diversity in semi-permanent wetlands relative to seasonal wetlands also may be due to the longer storage time of egg bank samples that influenced egg bank viability or diapause termination conditions (Wiggins et al. 1980, Dodson and Frey 1991, Moreira dos Santos and Persoone 1998). Additionally, the complete absence of insect taxa in both wetland classes is notable. Of three previous studies conducted that have employed methods similar to those used in our study to incubate invertebrates (Euliss and Mushet 1999, Euliss et al. 2001, Gleason et al. 2003), only the study by Euliss et al. (2001) resulted in the incubation of a few insect taxa (i.e., Chironomidae and Coleoptera). It is likely that sample storage conditions influence viability of insect larva (e.g., chironomids) or that environmental conditions were unfavorable for hatching of insect eggs (e.g., mosquitoes; Horsfall 1956, Horsfall and Fowler 1961).

We were unable to detect a significant relationship 


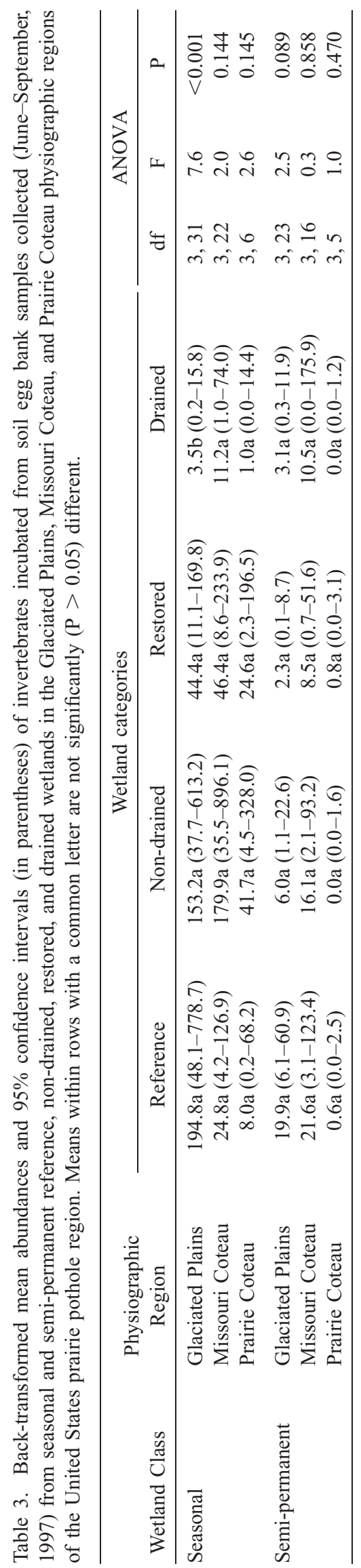

between restoration age and taxon richness or invertebrate abundances, but small sample sizes and low taxonomic resolution may have precluded our ability to detect such a relationship. However, comparison of restored wetland invertebrate egg banks among regions suggests that drainage of wetlands in the landscape and associated agricultural land-use practices may be more important explanatory variables than restoration age (Figure 4). For both seasonal and semi-permanent wetlands, development of egg banks in restored wetlands relative to reference wetlands was less successful (richness and abundance) in the Glaciated Plains than in the Coteau regions (Figure 4). The most obvious difference among regions that might explain this variation is the extent of wetland drainage, which has been far greater in the Glaciated Plains than in the Coteau regions (Figure 4). Thus, more intense wetland drainage in the Glaciated Plains has decreased the numbers of wetlands in the landscape that may serve as invertebrate sources to repopulate restored wetlands. Additionally, wetlands in the Glaciated Plains typically have been drained more efficiently and drained and farmed for a longer duration than wetlands in the Coteau regions (Galatowitsch and van der Valk 1994). Both prolonged drainage and cultivation have been shown to impact invertebrate egg banks negatively (Euliss et al. 2001), as have other factors associated with intensive agricultural, such as crushing from vehicle traffic (Hathaway et al. 1996) or burial from accelerated sedimentation (Gleason et al. 2003). Although trends were observed among regions in the number of restored wetlands that attained taxon richness and abundance values similar to reference wetlands, substantial variation within regions remains unexplained. It is likely that more precise information on wetland density and type near each restored wetland (e.g., potential invertebrate sources) and detailed information on drainage and agricultural histories might better explain variation in success of restorations.

\section{MANAGEMENT IMPLICATIONS}

Our research suggests that development of egg banks in restored semi-permanent wetlands may be impeded relative to restored seasonal wetlands. Further, trends in our data suggest that this difference occurs throughout the PPR regardless of physiographic region. The primary reason for this difference is likely the frequency and extent of seasonal drying that promotes production of resting eggs. Differences in hydroperiods among wetland types are beneficial because they increase diversity of plants and invertebrates within the landscape or wetland complex (Swanson and Duebbert 1989). However, some restored wetlands are equipped with water-control structures, and manip- 


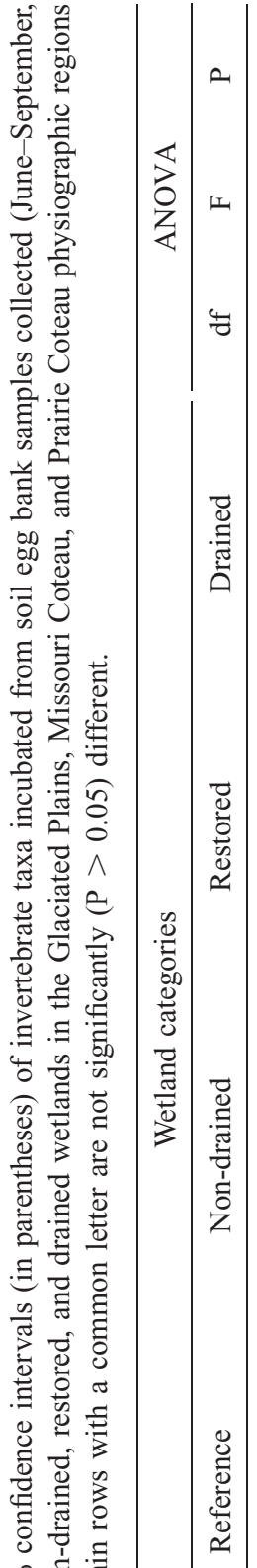

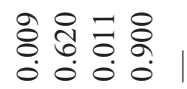

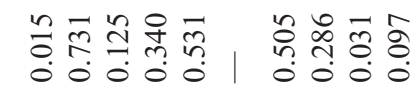

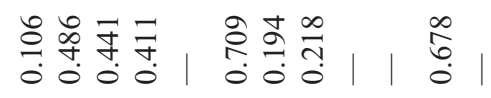

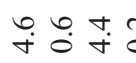

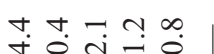

$0.00 \%$

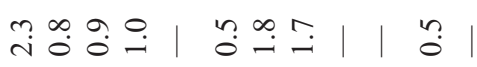

जन्लेक

สสกสส

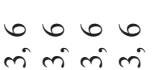

สึกส กี

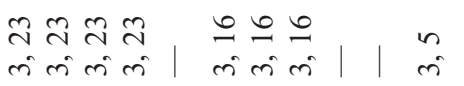

mं

लंmं

กิฺ

$\tilde{\sigma} \hat{\sigma} \frown \hat{\sigma} \sigma$

6 으.

1.

?ं

$\ddot{e} \dot{e} \dot{e}$

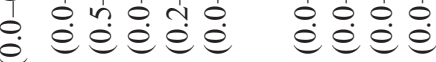

뉴

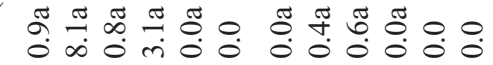

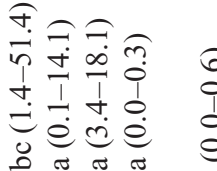

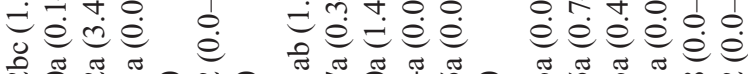

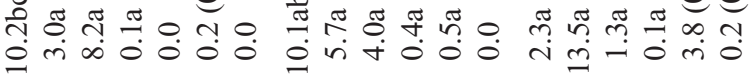

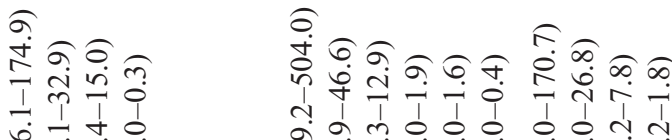

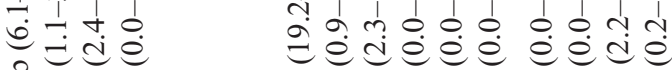

崔

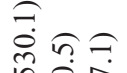

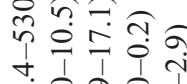

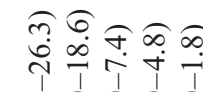

กิ่

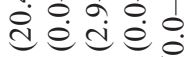

‘்

IT की

光

设

चี

\&े $\sum^{\infty} \sum^{\infty}$

营苛.

है ज

콩

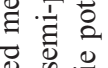

预

㫕芯

蓄芯芯

过

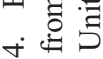

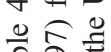

츤
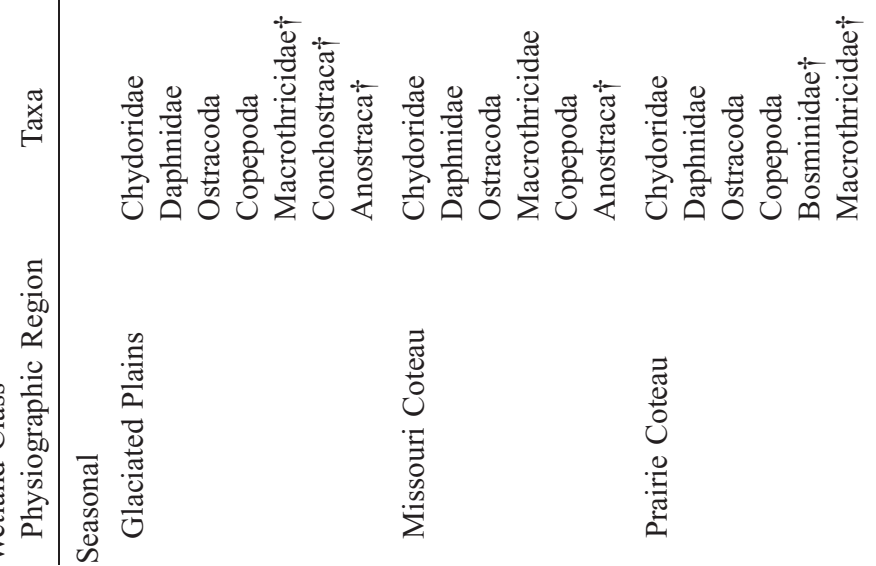

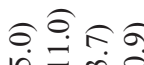

वाल मे

eेe

สิ่อิ์

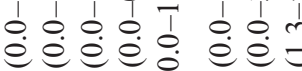

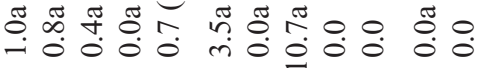

สิธิกิก กิ

गิ

e $\dot{e} \dot{0}$

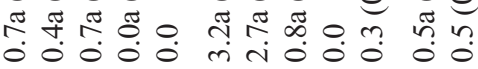

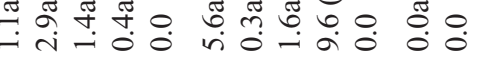

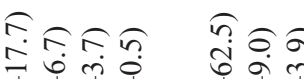

官它它它

莳尔 

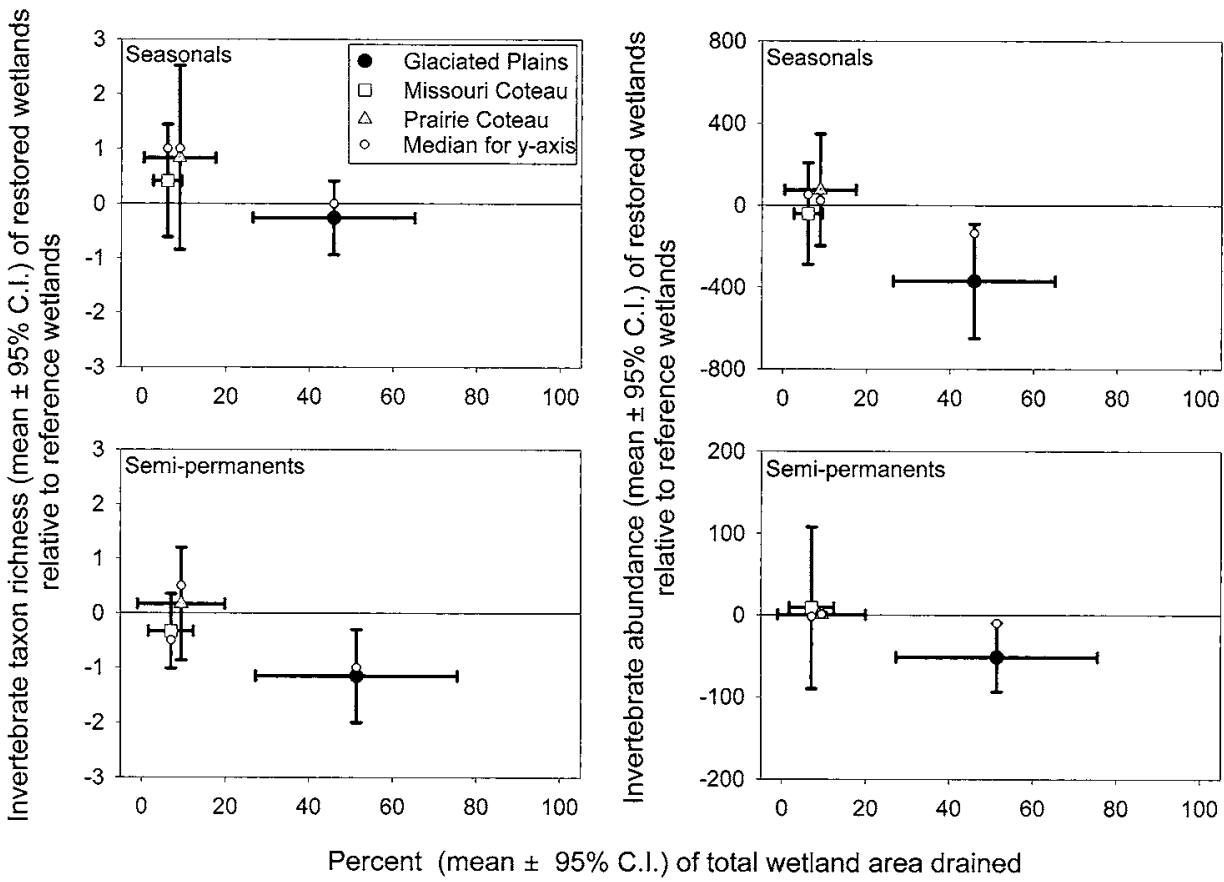

Figure 4. Relationship between mean invertebrate taxon richness (left) and abundance (right) with mean percent of total wetland area drained in each physiographic region by wetland class. Mean estimates of percent wetland area drained are based on county-level estimates where restored wetlands were sampled. Taxon richness and abundance values used for estimating means represent difference in taxon richness and abundance in restored wetlands from their paired reference wetlands. Mean and $95 \%$ confidence intervals below the zero line indicate that average invertebrate taxon richness or abundance in restored wetlands were lower than in reference wetlands. Invertebrates were incubated from soil egg bank samples collected (JuneSeptember 1997) from seasonal and semi-permanent restored wetlands and reference wetlands in the Glaciated Plains, Missouri Coteau, and Prairie Coteau physiographic regions of the United States prairie pothole region.

ulation of water levels may offer potential to stimulate production of invertebrate propagules. For example, hydroperiods can be manipulated to provide environmental cues necessary for embryonic development and hatch of dominant egg bank taxa (e.g., Cladocera, Ostracoda) (Neckles et al. 1990). Some restored wetlands in the southern PPR receive water collected from tile lines outside of their catchments and often have artificially lengthened hydroperiods (Galatowitsch and van der Valk 1994). Such wetlands may benefit the most from water-level manipulations that trigger production of invertebrate resting eggs. Management efforts in such systems should focus on techniques that mimic seasonal and interannual variations in hydroperiods associated with various wetland types (e.g., temporary, seasonal, semi-permanent).

Our research also indicated that recovery of invertebrate egg banks was not related to time. Thus, other factors such as wetlands drainage or site specific disturbances have impeded the natural recovery process. Based on our results, we cannot conclude that invertebrate egg banks are adequately recovering in all restored wetlands through natural processes. Inoculation of restored wetlands with remnant wetlands soils may result in faster recolonization of wetlands by invertebrates (Brown et al. 1997), and future research should evaluate the benefits of such inoculations on the recolonization and development of invertebrate egg banks in restored prairie wetlands.

\section{ACKNOWLEDGMENTS}

This project would not have been possible without the assistance and cooperation of many state and federal personnel from the U.S. Fish and Wildlife Service (Region 3 and 6), U.S. Department of Agriculture's Natural Resources Conservation Service, Minnesota Department of Natural Resources, South Dakota Department of Game, Fish, and Parks, and Iowa Department of Natural Resources. Additionally, we are indebted to the many land owners in Montana, North Dakota, South Dakota, Minnesota, and Iowa for granting access to wetlands on private lands. A special thanks goes to Paul Coughlin of the South Dakota Department of Game, Fish, and Parks for participating in a U.S. Department of Interior State partnership proposal to acquire funding for this project. We also thank Brian Check and Chris Locken for their assistance 

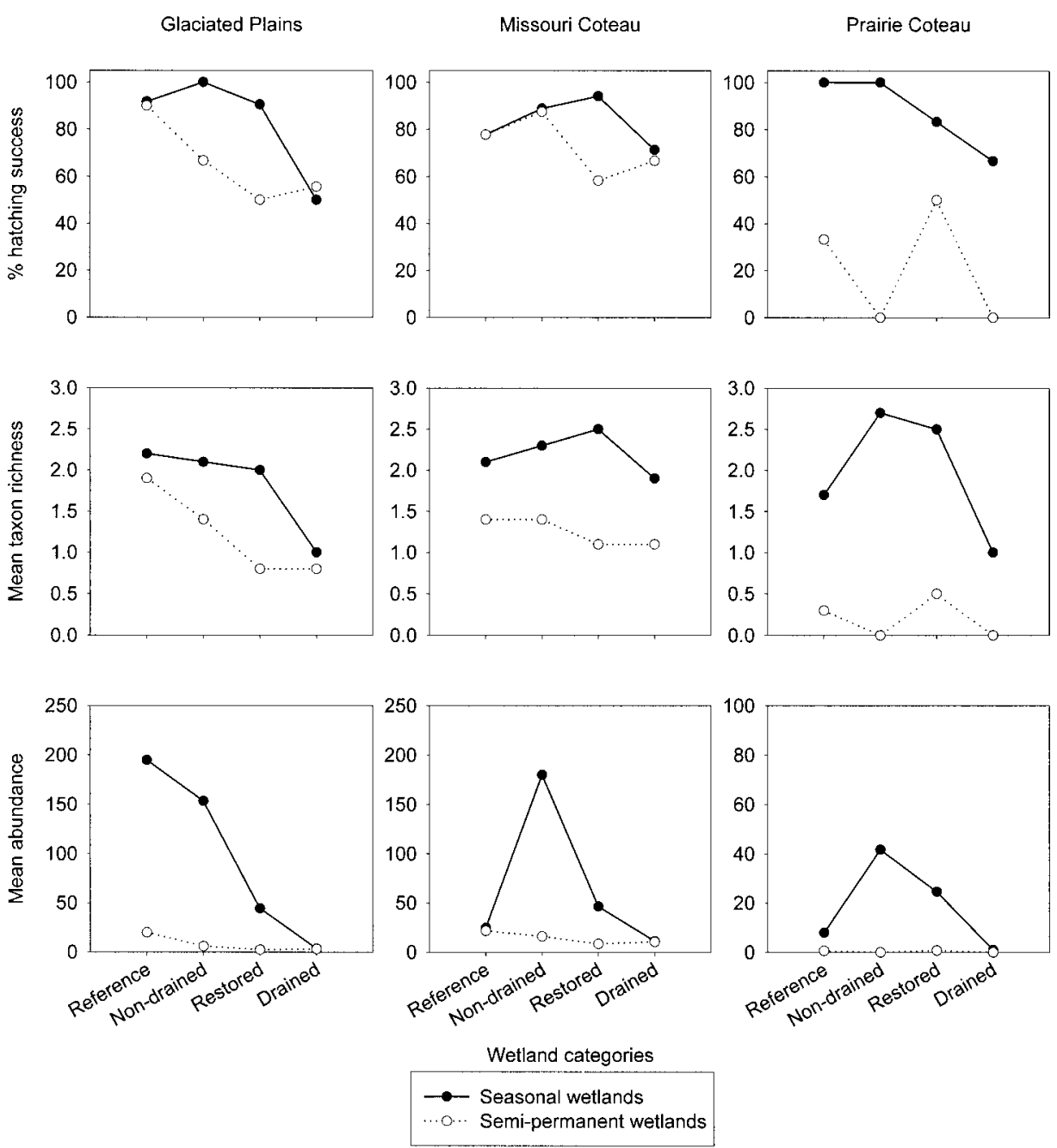

Figure 5. Hatching success and mean taxon richness and abundance of inverterbrates incubated from soil egg banks samples collected (June-September 1997) from seasonal and semi-permanent reference, non-drained, restored, and drained wetlands in the Glaciated Plains, Missouri Coteau, and Prairie Coteau physiographic regions of the United States prairie pothole region.

with laboratory work, Wesley Newton and Deb Buhl for their statistical assistance, David Mushet and Bruce Hanson for coordinating many activities related to this project, and Ann Dahl and Tom Sklebar for providing GIS and mapping assistance. We also thank Kyle Zimmer, Murray Laubhan, and David Mushet for providing editorial review on an earlier draft of this manuscript.

\section{LITERATURE CITED}

Bluemle, J. P. 1977. The Face of North Dakota: the Geologic Story. North Dakota Geological Survey, Bismarck, ND, USA. Educational Series 11

Brown, S. C., K. Smith, and D. Batzer. 1997. Macroinvertebrate responses to wetland restoration in northern New York. Environmental Entomology 26:1016-1024.

Delphey, P. J. 1991. A comparison of the bird and aquatic macroinvertebrate communities between restored and natural Iowa prairie wetlands. M.S. Thesis. Iowa State University, Ames, IA, USA.
De Stasio, B. T., Jr. 1989. The seed bank of a freshwater crustacean: copepodology for the plant ecologist. Ecology 70:1377-1389.

Dieter, C. E. 1991. Water turbidity in tilled and untilled prairie wetlands. Journal of Freshwater Ecology 6:185-189.

Dodson, S. I. and D. G. Frey. 1991. Cladocera and other branchiopoda. p. 723-726. In J. H. Thorp and A. P. Covich (eds.) Ecology and Classification of North American Freshwater Invertebrates. Academic Press, Inc., San Diego, CA, USA.

Downing, J. A. 1979. Aggregation, transformation, and the design of benthos sampling programs. Journal of the Fisheries Research Board of Canada 36:1454-1463.

Elliott, J. M. 1977. Some methods for the statistical analysis of samples of benthic invertebrates. 2nd ed. Freshwater Biological Association Scientific Publication No. 25.

Euliss, N. H., Jr. and D. M. Mushet. 1999. Influence of agriculture on aquatic invertebrate communities of temporary wetlands in the prairie pothole region of North Dakota, USA. Wetlands 19:578583.

Euliss, N. H. Jr., D. M. Mushet, and D. H. Johnson. 2001. Use of macroinvertebrates to identify cultivated wetlands in the prairie pothole region. Wetlands 21:223-231.

Euliss, N. H. Jr., D. A. Wrubleski, and D. M. Mushet. 1999. Wetlands in the prairie pothole region: invertebrate species composition, ecology, and management. p. 471-514. In D. P. Batzer, R. 
B. Rader, and S. A. Wissinger (eds) Invertebrates in Freshwater Wetlands of North America: Ecology and Management. John Wiley \& Sons, Inc. New York, NY, USA.

Galatowitsch, S. M. and A. G. van der Valk. 1994. Restoring Prairie Wetlands: an Ecological Approach. Iowa State University Press, Ames, IA, USA.

Gleason, R. A. 2001. Invertebrate egg and plant seed banks in natural, restored, and drained wetlands in the prairie pothole region (USA) and potential effects of sedimentation on recolonization of hydrophytes and aquatic invertebrates. Ph.D. Dissertation. South Dakota State University, Brookings, SD, USA.

Gleason, R. A. and N. H. Euliss, Jr. 1998. Sedimentation of prairie wetlands. Great Plains Research 8:97-112.

Gleason, R. A., N. H. Euliss, Jr., D. E. Hubbard, and W. G. Duffy. 2003. Effects of sediment load on emergence of aquatic invertebrates and plants from wetland soil egg and seed banks. Wetlands 23:26-34.

Grue, C. E., L. R. DeWeese, P. Mineau, G. A. Swanson, J. R. Foster, P. M. Arnold, J. N. Huckins, P. L. Sheehan, W. K. Marshall, and A. P. Ludden. 1986. Potential impacts of agricultural chemicals on waterfowl and other wildlife inhabiting prairie wetlands: an evaluation of research needs and approaches. Transactions of the North American Wildlife and Natural Resources Conference 51: 357-83.

Hairston, N. G., Jr., R. A. Van Brunt, and C. M. Kearns. 1995. Age and survivorship of diapausing eggs in a sediment egg bank. Ecology $76: 1706-1711$

Hathaway, S. A., D. P. Sheehan, and M. A. Simovich. 1996. Vulnerability of branchiopod cysts to crushing. Journal of Crustacean Biology 6:448-452.

Hemesath, L. M. 1991. Species richness and nest productivity of marsh birds on restored prairie potholes in northern Iowa. M.S. Thesis. Iowa State University, Ames, IA, USA.

Horsfall, W. R. 1956. Eggs of floodwater mosquitoes III (Diptera, Culicidae): conditioning and hatching of Aedes vexans. Annals of the Entomological Society of America 49:66-71.

Horsfall, W. R. and H. W. Fowler, Jr. 1961. Eggs of floodwater mosquitoes VIII: effect of serial temperatures on conditioning of eggs of Aedes stimulans Walker (Diptera: Culicidae). Annals of the Entomological Society of America 54:664-666.

Kantrud, H. A. 1993. Duck nest success on conservation reserve program land in the prairie pothole region. Journal of Soil and Water Conservation 48:238-242.

LaGrange, T. G. and J. J. Dinsmore. 1989. Plan and animal community responses to restored Iowa wetlands. Prairie Naturalist 21: 39-48.

Martin, D. B. and W. A. Hartman. 1987. The effect of cultivation on sediment composition and deposition in prairie pothole wetlands. Water, Air, \& Soil Pollution 34:45-53.

Milliken, G. A. and D. E. Johnson. 1984. Analysis of Messy Data, Volume 1: Designed Experiments. Van Nostrand Reinhold Company, New York, NY, USA.
Moreira dos Santos, M. M. and G. Persoone. 1998. Hatching of Daphnia magna resting eggs: the effect of storage duration and storage temperature. Advances in Limnology 53:253-262.

Neely, R. K. and J. L. Baker. 1989. Nitrogen and phosphorus dynamics and the fate of agricultural runoff. p. 92-131. In A. G. van der Valk (ed.) Northern Prairie Wetlands. Iowa State University Press, Ames, IA, USA.

Neckles, H. A., H. R. Murkin, and J. A. Cooper. 1990. Influences of seasonal flooding on macroinvertebrate abundance in wetland habitats. Freshwater Biology 23:311-322.

Pennak, R. W. 1989. Fresh-water Invertebrates of the United States. 3rd edition, John Wiley and Sons, New York, NY, USA.

Resh, V. H. 1979. Sampling variability and life history features: basic considerations in the design of aquatic insect studies. Journal of the Fisheries Reesearch Board of Canada 36:290-311.

SAS Institute, Inc. 1989. SAS/STAT user's guide, Version 6, fourth edition, volume 2. SAS Institute, Cary, NC, USA.

SAS Institute, Inc. 1997. SAS/STAT software: changes and enhancements through release 6.12. SAS Institute, Cary, NC, USA.

Sewell, R. W. 1989. Floral and faunal colonization of restored wetlands in west-central Minnesota and northeastern South Dakota. M.S. Thesis. South Dakota State University, Brookings, SD, USA.

Steel, R. G. D. and J. H. Torrie. 1980. Principles and Procedures of Statistics: a Biometrical Approach. McGraw Hill Book Company, New York, NY, USA.

Stewart, R. E. and H. A. Kantrud. 1971. Classification of natural ponds and lakes in the glaciated prairie region. U.S. Fish and Wildlife Service Resource Publication 92.

Swanson, G. A. and H. F. Duebbert. 1989. Wetland habitats of waterfowl in the prairie pothole region. p. 228-267. In A. G. van der Valk (ed.) Northern Prairie Wetlands. Iowa State University Press, Ames, Iowa, USA.

U.S. Department of Agriculture, Soil Conservation Service (USDA/ SCS). 1994. The 1992 National Resources Database. U.S. Department of Agriculture, Soil Conservation Service, Washington, DC, USA.

van der Valk, A. G. 1981. Succession in wetlands: a Gleasonian approach. Ecology 62:688-696.

van der Valk, A. G. and C. B. Davis. 1978. The role of seed banks in the vegetation dynamics of prairie glacial marshes. Ecology 59: 322-335.

VanRees-Siewert, K. L. 1993. The influence of wetland age on bird and macroinvertebrate use of restored Iowa wetlands. M.S. Thesis. Iowa State University, Ames, IA, USA.

Visher, S. S. 1966. Climatic Atlas of the United States. Harvard University Press, Cambridge, MA, USA.

Wiggins, G. B., R. J. Mackay, and I. M. Smith. 1980. Evolutionary and ecological strategies of animals in annual temporary pools. Archiv für Hydrobiologie Supplement 58:97-206.

Manuscript received 9 September 2002; revisions received $26 \mathrm{Au}-$ gust 2003 and 23 March 2004; accepted 19 May 2004. 